\title{
Electre Method in Selection of a Seventh Party Logistics Provider (7pl)
}

\section{J. Praveena, M. Pramila Devi}

\begin{abstract}
The main aim of this paper is to evaluate and select a Seventh Party logistic service provider as a Multi criteria Decision Making Problem using Electre Method. This method allows in outranking and choosing a promising 7PL among the alternatives by consider various parameters. Evaluation and selection procedure is discussed in detail. Electre method is often used for ranking among alternatives.
\end{abstract}

Keywords: multi-criteria decision making Electre method, Seventh party logistics,, criteria selection.

\section{INTRODUCTION}

Logistics is one of the important factors in integrating the supply chain of industries. Because of the increasing global markets, logistics services are now seen as field areas where industries can improve customer service and decrease costs [1]. Many industries are in search to find suitable outsourcings logistics services to seven party logistics providers to introduce services and product innovations quickly to into markets[2].Therefore, almost manufacturing companies are following trend of out sourcing their logistics activities to meet their need for logistics services. This trend improved of the concept of service provider [3]. Many industries are using these service of providers to fulfill their all logistic needs[4].Out sourcing is defined as an organization that hires an outside organization to provide a service or product that is needed because the organization may not provide itself [5]. With development of supply chain partnerships many companies are now outsourcing for using supply chain management, efficient and provide improved services and better logistics operations. Companies prefer to outsource their logistics services to 7PL service providers [6]. A 7PL is defined as a logistics services provider that performs all functions of logistics and integrates all operations on part of their customer [7]. The selection process is complex for multi-criteria decision making problem that includes both qualitative and quantitative criteria [8]. MCMD is an important function of the logistics as it signify for the companies assessment. While selecting the appropriate 7PL service provider, logistics managers has to justify the needs of the company which should be satisfied by the logistic service provider [9].

Revised Manuscript Received on March 17, 2020.

*correspondence Author:

J. Praveena*, Department of Mechanical Engineering, Andhra University, Visakhapatnam, Andhra Pradesh, India. Email: jannavarapu.veena@gmail.com.

Prof. M.Pramila Devi, Department of Mechanical Engineering, Andhra University, Visakhapatnam, Andhra Pradesh, India. Email: pramiladevi_m@yahoo.co.in

(C) The Authors. Published by Blue Eyes Intelligence Engineering and Sciences Publication (BEIESP). This is an open access article under the CC BY-NC-ND license (http://creativecommons.org/licenses/by-nc-nd/4.0/)
In MCDM problems which we often come across are subjectivity, vagueness, uncertainty, and ambiguity in assessment process [10], we can study structure evaluation and calculate weights of the important criteria's uses analytical hierarchy process (AHP) and group of decisionmakers according to obtain the final order of ranking of logistics service providers. Therefore, with this evaluation of the performance of seventh party logistics service providers of a company in a developed and developing countries, via the proposed AHP and Electre techniques as Multi Criteria Decision Making problems. With the AHP we can find the relative weights of evaluation criteria. Then, this method of research helps in evaluating and determining the performance of seventh party logistics service providers and the best alternatives among given companies is found out. The objective of this paper is organized as follows. Section2 presents a literature survey on logistics services, logistics management in companies and uses of logistics service provider.

This also includes selection of criteria used for evaluating performances 7PL and evaluation methods 7PL performances.Section3 describes methodology that helps in selection of seventh party logistics service providers using Electre method. The proposed methodology for selection of seventh party logistics service provider is performed for a company. In Section 4, we conclude by considering the limitation and managerial improvements of this study are discussed.

\section{Seventh Party Logistic Service Provider (7PL)} Structure:

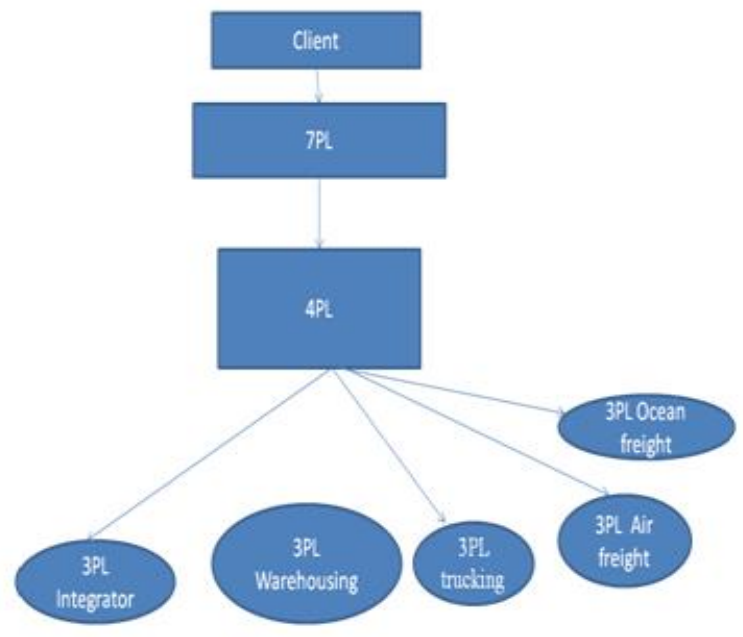

II. ELECTRE METHOD

ELECTRE Method was first proposed by B. Roy in early 1960 's later this method was connected in various fields to deal with multi criteria's issues.

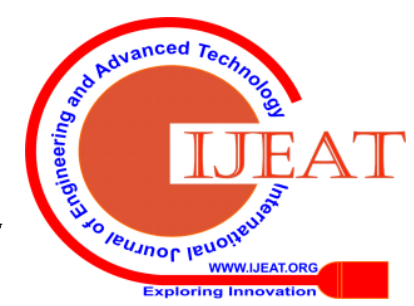


This method gives the main choice, when one choice is contrasted over another choice. Possible choice upon concordance set, harshness grid and a level values we can discover predominance between the choices. Hence positioning of choices can be found by depending upon the elements of concordance, conflict strength grids.

\section{Electre Method:}

Step 1: Formation of Matrix (A) for Decision making:

Decision values that will be rated according to their supremacies taking part in the sequence and the evaluation criteria's to be used in decision making are taking part in the columns of the decision matrix.

A matrix representing the model is formed by the decision maker. Matrix taken by the decision maker is shown as follows:

$$
\mathrm{A}_{\mathrm{ij}}=\left(\begin{array}{cccc}
a 11 & a 12 \ldots \ldots \ldots & a 1 n \\
a 21 & a 22 \ldots \ldots \ldots & a 2 n \\
\cdot & \cdot & & \cdot \\
\cdot & \cdot & & \cdot \\
a m 1 & a m 2 \ldots \ldots \ldots & a m n
\end{array}\right)
$$

$m$ gives the number of decision values and $n$ gives the number of evaluation criteria's in matrix.

\section{Step 2: Formation of Matrix (X) in Standard Decision values:}

Standard decision matrix is calculated by using the elements of Aij matrix and the formula below.

$$
\mathrm{X}_{\mathrm{ij}}=\frac{a i j}{\sqrt{\sum_{k=1}^{m} a_{k j}^{2}}}
$$

The $\mathrm{X}$ matrix is calculated as follows in the result shown below:

$$
\mathrm{X}_{\mathrm{ij}}=\left(\begin{array}{ccc}
x 11 & x 12 \ldots \ldots \ldots & x 1 n \\
x 21 & x 22 \ldots \ldots \ldots & x 2 n \\
\cdot & \cdot & \cdot \\
\cdot & \cdot & \cdot \\
x m 1 & x m 2 \ldots \ldots \ldots & x m n
\end{array}\right)
$$

Step 3: Formation of Matrix (Y) as weighted Standard Decision values:

The evaluation criteria's based on the weights will be different for decision making. Matrix (Y) is calculated for representing the differences in weights to find solution using Electre method. Firstly the weights of the evaluation criteria's ( wi ) should be defined by the decision maker and the summation of these criteria weights should be calculated as $\left(\sum_{\mathrm{i}=1}^{\mathrm{n}} \mathrm{w}_{\mathrm{i}}=1\right)$

Then the values of $\mathrm{X}$ matrix in each column are multiplied with wi value of relevance and matrix $\mathrm{Y}$ is then calculated. The matrix $\mathrm{Y}$ is shown below:

$$
\mathrm{Y}_{\mathrm{ij}}=\left(\begin{array}{ccc}
w_{1} x_{11} & w_{1} x_{12} & w_{n} x_{1 n} \\
w_{1} x_{21} & w_{2} x_{22} & w_{n} x_{2 n} \\
\cdot & \cdot & \cdot \\
\cdot & \cdot & \cdot \\
w_{1} x_{m 1} & w_{2} x_{m 1} & w_{n} x_{m n}
\end{array}\right)
$$

Step 4: Finding the values for Conformity $\left(C_{k l}\right)$ and Nonconformity $\left(D_{k l}\right)$ grids:

After finding the values for matrix $\mathrm{Y}$ conformity grids are to be determined, the decision values are compared to one another with relation to the evaluated criteria's and the girds are formed by considering relation shown in the formula below. This comparison of the magnitudes of grids components are compared to each other mainly as: $\mathrm{Ckl}=\mathrm{j}$, ykj $\geq$ yij. A nonconformity grid ( Dkl) responses to each conformity grid ( Ckl ) using ELECTRE method. The conformity grids is same as the nonconformity grids in numbers. Every component of nonconformity grid having a $j$ values that does not belong to the same conformity grid.

Step 5: Formation of Matrices for Conformity (C) and Nonconformity (D) :

It is advantageous for conformity grids to the develop a (C) which is conformity matrix Matrix $\mathrm{C}$ is of the form $\mathrm{m} \mathrm{x} \mathrm{m}$ dimension and it can not take value for $k=1$. The values of matrix $\mathrm{C}$ are calculated by using of the formula shown below.

$\mathrm{C}_{\mathrm{kl}}=\sum_{j \in c_{k l}} w_{j}$

And the values of matrix (D) of nonconformity are calculated by using of the formula shown below:

$$
\mathrm{d} k \mathrm{kl}=\frac{\max \left|\mathrm{y}_{\mathrm{kj}}-\mathrm{y}_{\mathrm{ij}}\right| \mathrm{j} \in \mathrm{D}_{\mathrm{w}}}{\max |\mathrm{ykj}-\mathrm{yij}|}
$$

Matrix $\mathrm{D}$ is also $\mathrm{m} \mathrm{x} \mathrm{m}$ dimension and it can not take value for $\mathrm{k}=\mathrm{l}$. The matrix $\mathrm{D}$ is calculated using the formula as shown below:

$$
\left(\begin{array}{cccc}
\mathrm{D}_{\mathrm{ij}}= & & & \\
- & d_{12} & d_{13} \ldots \ldots \ldots & d_{1 m} \\
d_{21} & - & d_{23} \ldots \ldots \ldots & d_{2 m} \\
\cdot & \cdot & . & \\
\cdot & \cdot & . & \\
d_{m 1} & d_{m 2} & d_{m 3} \ldots \ldots \ldots \ldots \ldots
\end{array}\right)
$$

Step 6: Formation of matrix (F) for Conformity Supremacy and matrix $(G)$ for Nonconformity Supremacy:

The matrix (F) for Conformity supremacy is $\mathrm{m} \mathrm{x} \mathrm{m}$ dimensions and the values of the matrix are resulted by the comparison of conformity phenomenon value as ( $\underline{c})$ with the values of conformity matrix ( ckl ). Conformity phenomenon value (c $)$ calculated by using of the formula as shown below:

$$
\underline{c}=\frac{1}{m(m-1)} \sum_{k=1}^{m} \quad \sum_{l=1}^{m} c_{k l}
$$

$\mathrm{m}$ is the required number of decision values as shown in the formula. Therefore, the value of $\mathrm{c}$ is equal to $\frac{1}{\mathrm{~m}(\mathrm{~m}-1)}$ multiplication times and the total of all the values are found from the matrix $\mathrm{C}$. The values of matrix $\mathrm{F}$ as (fkl ), will take the value as either 1 or 0 and the diagonal value of the matrix is not considered due to the condition as shown at the same decision values. If $\mathrm{ckl} \geq \underline{\mathrm{c}} \rightarrow \mathrm{fkl}=1$, and if $\mathrm{ckl}$ $\leq \underline{\mathrm{c}} \rightarrow \mathrm{fkl}=0$.

The matrix $\mathrm{G}$ for Nonconformity supremacy is also taken in the form $\mathrm{m} \mathrm{x} \mathrm{m}$ dimension and it is used to find similarly to matrix F.

Published By:

Blue Eyes Intelligence Engineering

\& Sciences Publication

(C) Copyright: All rights reserved. 
The phenomenon values for nonconformity ( $\underline{\mathrm{d}})$ is calculated by using of the formula shown below:

$\underline{\mathrm{d}}=\frac{1}{\mathrm{~m}(\mathrm{~m}-1)} \sum_{\mathrm{k}=1}^{\mathrm{m}} \quad \sum_{\mathrm{l}=1}^{\mathrm{m}} \mathrm{d}_{\mathrm{kl}}$

The value of the matrix $G$ as ( $g k l$ ) will also take the values as either 1 or 0 values and the diagonal of the matrix is not considered due to the condition as shown at the same decision values. If $\mathrm{dkl} \geq \underline{\mathrm{d}} \rightarrow$

$\mathrm{gkl}=1$, and if $\mathrm{dkl} \leq \underline{\mathrm{d}} \rightarrow \mathrm{gkl}=0$.

Step 7: Formation of Matrix (E) for Finding Total Dominance values:

The values of the matrix (E) for total dominance matrix are equal to $f_{k l}$ multiplied to $g_{k l}$ values resulting as $\left(e_{k l}\right)$. Here, the matrix $\mathrm{E}$ is $m \times m$ dimension depending upon the matrices $F$ and $G$ and again results in 1 or 0 values.

Step 8: Determining the Order of importance for the Decision values:

The rows and columns of the matrix $\mathrm{E}$ represent the decision values as 0 and 1 These values in the matrix are examined and dominance with absolute value is found and the order of importance for the decision value is found.

\section{METHODOLOGY}

As an illustration application by considering a case in which one wishes to chose best 7PL service provider using criteria's. The above issue we are observe on finding the relative importance for the considering number of alternatives under examination. The decision makers wishes to evaluate the model, a company wishes to outsource its entire activities related to logistics. The judegment of manager of logistics for a company, sorts with the help of comparison between pair wise matrices after the finding the initial list of useful logistics service providers, namely A, B, $\mathrm{C}$ companies were compared for selecting best logistics service providers among them. A company is assert based and it has its own transport, shipping, warehouse, freight operations and distribution. B is company with similar advancements in it and management capabilities changes, however another the logistic service provider $\mathrm{C}$ is a company which is non assert based company and this company prefers in out sourcing instead of having own physical asserts for all its logistics operations as per the needs of the clients.

\section{RESULTS}

According to research result, the company B is preferred over company $\mathrm{A}$ is in second position and the company $\mathrm{C}$ is last in order . So its clear that company B is more efficient than the other two options companies A and C. Therefore ,we can use this method for evaluation of other complex multi-criteria decision making problems.

\section{CONCLUSIONS}

The objective of our study is to determine the appropriate selection of best seventh party logistics provider through Electre method as multiple -criteria decision making method. We need to determine the logistic services for a company to establish in selection of different criteria's and weights relative to the criteria's in order to obtain the final selection in this research paper.

\section{REFERENCES}

1. J. Yan, P. E. Chaudhry, and S. S. Chaudhry, "A model of a decision support system based on case-based reasoning for third-party logistics evaluation,", vol. 20, no. 4, pp.196-207,2003.

2. K.-H. Lai, "Service capability and performance of logistics service providers," Transportation Research E: Logistics and TransportationReview,vol.40,no.5,pp.385-399,2004.

3. P. M. Panayides and M. So, "Logistics service provider-client relationships," Transportation Research E: Logistics and TransportationReview,vol.41,no.3,pp.179-200,2005.

4. K. G. G"ulen, "The extension of the outsourcing in logistics services and development strategies of supplier firms," Istanbul Commerce University Journal of Science (Ticaret "UniversitesiFen BilimleriDergisi),vol.4,no.8,pp.29-48,2005.

5. M. L. Douglas, R. S. James, and M. E. Lisa, Fundementals of LogisticsManagement,McGraw-Hill,NewYork,NY,USA,1998.

6. S. Jharkharia and R. Shankar, "Selection of logistics service provider: an analytic network process (ANP) approach," Omega,vol.35,no.3,pp.274-289,2007.

7. W.Delfmann, S.Albers ,and M.Gehring, "The impact of electronic commerce on logistics service providers," International JournalofPhysicalDistribution\&LogisticsManagement,vol.32, no.3,pp.203-222,2003.

8. E. C,akır, H. Tozan, and O. Vayvay, "A method for selectıng third party logistic service provider using fuzzy AHP," Journal ofNavalScienceandEngineering,vol.5,no.3,pp.38-54,2009.

9. M. Bevilacqua and A. Petroni, "From traditional purchasing to supplier management: a fuzzy logic-based approach to supplier selection," International Journal of Logistics: Research andApplications,vol.5,no.3,pp.28-46,2002.

10. Z. Turskis, E. K. Zavadskas, and F. Peldschus, "Multi-criteria optimization system for decision making in construction design and management,"EngineeringEconomics,vol.1,no.61,pp.7-17, 2009.

11. Republic of Turkey Prime Ministry, Invesment Support and Promotion Agency, The Logistics Industry in Turkey, "Transportation and Logistics Industry Report,’2013.

\section{AUTHOR PROFIL}

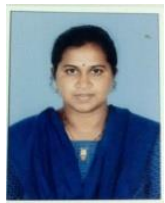

J.Praveena, working as Assistant Prossesor on contract in Department of Mechanical Engineering at Andhra University College of Engineering for Women, Visakhapatnam, Andhra pradesh , india Currently pursuing Ph.d in the department of mechanical engineering , Andhra university, Visakhaptnam . Having a teaching experience of 11 years.

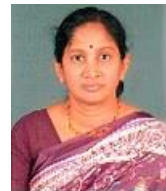

Prof. M. Pramila devi she is currently working as professor in the mechanical engineering department,Andhra university,Visakhapatnam, Andhra Pradesh, india.

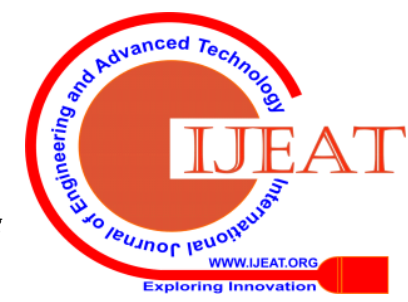




\section{APPENDIX}

\begin{tabular}{|c|c|c|c|c|c|c|c|c|c|}
\hline \multirow[b]{2}{*}{ weights } & \multicolumn{9}{|c|}{ THE DECISION MATRIX } \\
\hline & 0.3 & 0.09 & 0.07 & 0.04 & 0.03 & 0.11 & 0.31 & 0.05 & $\begin{array}{c}\text { Final } \\
\text { priority }\end{array}$ \\
\hline & $\mathrm{c} 1$ & c2 & c3 & $\mathrm{c} 4$ & c5 & c6 & c7 & c8 & \\
\hline a1 & 0.735 & 0.07 & 0.7333 & 0.054 & 0.745 & 0.6875 & 0.276 & 0.7025 & 0.498 \\
\hline $\mathrm{a} 2$ & 0.181 & 0.277 & 0.065 & 0.233 & 0.181 & 0.0865 & 0.623 & 0.065 & 0.331 \\
\hline a3 & 0.084 & 0.6525 & 0.2017 & 0.713 & 0.065 & 0.226 & 0.101 & 0.0715 & 0.188 \\
\hline
\end{tabular}

\begin{tabular}{|c|c|c|c|c|c|c|c|c|}
\hline & \multicolumn{9}{|c|}{ THE NORMALIZING THE DECISION MATRIX } \\
\hline & & & & & & & \\
\hline \\
\hline
\end{tabular}

\begin{tabular}{|c|c|c|c|c|c|c|c|c|}
\hline & c1 & c2 & c3 & c4 & c5 & c6 & c7 & c8 \\
\hline a1 & 0.2895 & 0.0088 & 0.0672 & 0.00287 & 0.02939 & 0.10375 & 0.124 & 0.0495 \\
\hline a3 & 0.033 & 0.0824 & 0.0184 & 0.03799 & 0.00253 & 0.0341 & 0.0452 & 0.01325 \\
\hline
\end{tabular}

\begin{tabular}{|c|c|c|c|c|}
\hline & \multicolumn{3}{|c|}{ C = CONCORDANCE MATRIX } & \\
\hline & a1 & a2 & a3 & \\
\hline a1 & 0 & 0.45 & 0.31 & \\
\hline $\mathrm{a} 2$ & 0.55 & 0 & 0.69 & \\
\hline \multirow[t]{3}{*}{ a3 } & 0.13 & 0.27 & 0 & \\
\hline & 0.68 & 0.72 & 1 & 2.4 \\
\hline & CBAR & & 0.4 & \\
\hline
\end{tabular}

\begin{tabular}{|c|c|c|c|c|}
\hline & \multicolumn{3}{|c|}{$\begin{array}{c}\mathbf{D}=\text { DISCONCORDANCE } \\
\text { MATRIX }\end{array}$} & \\
\hline & a1 & $\mathrm{a} 2$ & a3 & \\
\hline a1 & 0 & 0.504 & 0.9134 & \\
\hline $\mathrm{a} 2$ & 1 & 0 & 0.93987 & \\
\hline \multirow[t]{3}{*}{ a3 } & 1 & 1 & 0 & \\
\hline & 2 & 1.576 & 1.85327 & 5.429 \\
\hline & DBAR & & 0.9048 & \\
\hline
\end{tabular}

\begin{tabular}{|c|c|c|c|}
\hline & \multicolumn{3}{|c|}{$\begin{array}{c}\text { CONCORDANCE DOMINANCE } \\
\text { MATRIX }=\mathbf{f}_{\mathbf{k}}\end{array}$} \\
\hline & $\mathrm{a} 1$ & $\mathrm{a} 2$ & $\mathrm{a} 3$ \\
\hline $\mathrm{a} 1$ & 0 & 1 & 0 \\
\hline $\mathrm{a} 2$ & 1 & 0 & 1 \\
\hline $\mathrm{a} 3$ & 0 & 0 & 0 \\
\hline
\end{tabular}

\begin{tabular}{|c|c|c|c|}
\hline \multicolumn{4}{|c|}{$\begin{array}{c}\text { DISCONCORDANCE } \\
\text { DOMINANCE MATRIX = gll}\end{array}$} \\
\hline & a1 & $\mathrm{a} 2$ & a3 \\
\hline a1 & 0 & 0 & 1 \\
\hline a2 & 1 & 0 & 0 \\
\hline a3 & 1 & 1 & 0 \\
\hline
\end{tabular}

AGGREGATE DOMINANCE MATRIX $=\mathbf{e}_{1 \mathrm{k}}$

\begin{tabular}{|c|c|c|c|}
\hline & $\mathrm{a} 1$ & $\mathrm{a} 2$ & $\mathrm{a} 3$ \\
\hline $\mathrm{a} 1$ & 0 & 0 & 0 \\
\hline $\mathrm{a} 2$ & 1 & 0 & 1 \\
\hline $\mathrm{a} 3$ & 0 & 0 & 0 \\
\hline
\end{tabular}

